\title{
AC 2010-1721: PERCEPTIONS, EXPECTATIONS AND OUTCOMES OF THE THIRD YEAR OF A RESEARCH EXPERIENCES FOR UNDERGRADUATES PROGRAM
}

\section{David Willis, Southern Methodist University}

David A. Willis is an Associate Professor in the Department of Mechanical Engineering at Southern Methodist University (SMU). He received his B.S. degree from North Carolina State University in 1995 and his M.S. and Ph.D. degrees from Purdue University in 1997 and 2001, respectively. His areas of research interests are heat transfer, phase change, and fluid mechanics problems associated with short pulse laser-material interactions. His research involves experimental studies of laser microfabrication, high power laser-ablation, laser texturing, and laser-induced forward transfer. He has received the ASME North Texas Young Engineer of the Year Award, the SMU Rotunda Outstanding Professor Award, and the SMU Golden Mustang Award. He is currently an Altshular Distinguished Teaching Professor at SMU.

\section{Paul Krueger, Southern Methodist University}

Paul Krueger received his B.S. in Mechanical Engineering in 1997 from the University of California at Berkeley. He received his M.S. in Aeronautics in 1998 and his Ph.D. in Aeronautics in 2001, both from the California Institute of Technology (Caltech). In 2002 he joined the Mechanical Engineering Department at Southern Methodist University where he is currently an Associate Professor. He is a recipient of the Rolf D. Buhler Memorial Award in Aeronautics and the Richard Bruce Chapman Memorial Award for distinguished research in Hydrodynamics. In 2004 he received the Faculty Early Career Development Award (CAREER) from the National Science Foundation and in 2009 he received the ASME North Texas Section Young Engineer of the Year award. His research interests are unsteady hydrodynamics and aerodynamics, vortex dynamics, bio-fluid mechanics, and pulsed-jet propulsion.

\section{Alice Kendrick, Southern Methodist University}

Alice Kendrick is professor of advertising in the Temerlin Advertising Institute at Southern Methodist University in Dallas, Texas. Her research in advertising account planning, message content, and educational issues has appeared in journals including Journal of Advertising Research, Journal of Services Marketing, Journalism \& Mass Communication Quarterly, Journal of Advertising Education and Southwest Mass Communication Review. Her commentary and results of her work have also been featured in The Wall Street Journal, Advertising Age, Adweek, Incentive, The Dallas Morning News, Ragan's Newsletter, Los Angeles Daily News, and Promotional Products Business. She is co-author of two books and more than 30 refereed publications. In 2007 she received the Research Innovator Award from the Advertising Research Foundation. She holds the Ph.D. in Communications and M.S. in Adult Education from The University of Tennessee. 


\title{
Perceptions, expectations and outcomes of the Third Year of a Research Experiences for Undergraduates program
}

\begin{abstract}
Findings from a third-year study of a National Science Foundation Research Experiences for Undergraduates (REU) Site are presented in this paper. Ten students out of 79 applicants were selected to participate in hands-on experimental research in a mechanical engineering department for 8 weeks in the summer of 2009. The program matched students with faculty and graduate student mentors in several mechanical engineering laboratories, including experimental fluid dynamics, micro-sensors, laser micromachining, and advanced manufacturing. Participants attended seminars on experimental uncertainty, planning experiments, and presentation of experimental data. Students also attended field trips to local companies where they met with practicing mechanical engineers.
\end{abstract}

The REU students participated in before-program and after-program surveys and focus groups. The pre-post surveys indicated that as a result of the program students felt they had gained considerable hands-on experience, the ability to work with specialized equipment and methods of making engineering measurements, and that they were far more knowledgeable about engineering research. Eight out of 10 participants expressed a desire to attend engineering graduate school in both the pre- and post-surveys, though the number of students responding 'strongly agree' dropped from 5 to 2 in the post-survey.

Focus group discussions both pre- and post-program provided insight into a number of issues, including the "positioning" of an REU program as different from an internship or other summer employment; the arrival at more realistic expectations of the conduct of engineering research, including dealing with uncertainty, setbacks and logistical issues, and the absence of project closure in an 8-week time period; the impact of the struggling US economy on participants' decisions to apply for an REU program as well as the economic implications of pursuing a graduate degree; and the importance of an REU program in helping students determine "next steps" in both career and education. Implications for institutions involved in structuring, publicizing, and recruiting for REU programs are discussed.

\section{Description of the REU Site Program}

A Research Experiences for Undergraduates (REU) Site Program, funded by the National Science Foundation (NSF) was held during 8 weeks of the summer of 2009 at Southern Methodist University. The program was the final year of a three-year grant, and the results from the first two summers were published previously ${ }^{1,2}$. The purpose of this paper is to provide a summary of the final year of the program based on feedback from applicants and participants. Some of the evaluation questions were updated in the final year to reflect the possibility that student motivations for participating in the program were altered by the economy.

The theme of the program was "Experimental Methods in Mechanical Engineering," which was selected by the PIs due to the emphasis on experimental research by the majority of faculty in the 
department. The theme was also chosen because hands-on research is appealing to engineering students ${ }^{3}$ and can be a useful retention mechanism. ${ }^{4,5}$ The research laboratories that participated in the program were the Experimental Fluid Mechanics Laboratory, the Laboratory for Microand Nano-Mechanics of Materials, the Laser Micromachining Laboratory, the Research Center for Advanced Manufacturing, and the Micro Sensor Laboratory. Each faculty member submitted a list of possible projects from their research laboratory in which REU students could participate. Some of the projects were similar to those from previous years, while other projects were new to the REU program.

The REU program was advertised through an email message that was distributed to undergraduate engineering students at the host institution, faculty contacts at other universities, and the Women in Engineering Program Advocates Network (WEPAN) nationwide list-serve. The email message referred potential applicants to a website ${ }^{*}$ which was used as the central source of information for applicants. In addition to the promotional email, a link to the website was provided on a searchable NSF webpage ${ }^{\dagger}$ that listed all active REU sites. The SMU REU website provided details on program location, dates, stipend, housing accommodations, dining, research information, and application information. Research information included participating laboratories, faculty mentors, and potential project descriptions. Application information included eligibility requirements, contact information, application materials, and an optional applicant profile questionnaire. The required application materials were a standard application form, résumé, statement of purpose essay, transcript, 2 letters of recommendation, and rankorder list of at least 2 research projects. The application form required student contact information, college/university, academic major(s)/minor(s), and GPA.

The PIs selected participants from the applicant pool based on qualifications, interest in research, and preferred research topics. Minimum eligibility requirements for the program were sophomore standing or higher, 3.0 GPA, and a major in engineering or engineering science. Closely related majors in the sciences, such as materials science, physics, and chemistry were also considered if the major closely matched a project in which the applicant was interested. Matching of selected participants with faculty mentors was performed by the principal investigators (PIs), sometimes in consultation with potential faculty mentors, based on project preferences indicated by the applicants.

The first day of the program began with an orientation session focused on the program overview, schedule of activities, paperwork, campus tour, and a discussion of student expectations. The expectations discussion included an overview of the research environment, expected work hours, behavior in the research laboratory, and effective communication between participants and research mentors. After the first day of the program students reported directly to their research mentors. Since students were dispersed among 5 different research groups, the PIs organized group activities outside of the laboratory to facilitate the cohort experience. Cohort activities included living quarters in the same building, a social event on the Independence Day holiday, trips to local companies, and a seminar series. The trips to local companies were designed to expose participants to mechanical engineers working in design, manufacturing, and/or research. The 2009 program visits were to Alcon Laboratories, Texas Instruments, and Raytheon.

\footnotetext{
${ }^{*}$ http://lyle.smu.edu/REU

${ }^{\dagger}$ http://www.nsf.gov/crssprgm/reu/reu_search.cfm
} 
The seminar series was the main cohort activity of the program and required students to meet with the PIs weekly, except for the first and final week of the program. The seminars were developed and presented by the PIs, and the titles and descriptions are provided in Table 1 . The seminars emphasized aspects of experimental methods and were designed to provide skills that would benefit both their REU experience and their professional careers. The PIs also assigned the participants 3 activities related to their seminar experience: an uncertainty analysis, a final report, and a poster presentation competition. The uncertainty analysis was assigned after the completion of the "Uncertainty in Experiments" seminar and required participants to perform an uncertainty analysis related to their project. Although the students did not have much experience with their research projects at that time, the exercise required them to think independently and critically about their projects at an early stage in the program. This allowed the PIs to provide feedback long before the students had collected much data and gave significant time for students to implement feedback into their final reports and poster presentation. The final report required students to summarize their projects in a brief manner using information provided in the "Written Presentation of Results" seminar.

Table 1: REU Seminars on Experimental Methods in Mechanical Engineering

\begin{tabular}{|l|l|}
\hline Seminar Title & Description \\
\hline The Purpose of Measurements & Overview of the types of experiments and their purposes \\
\hline Uncertainty in Experiments & $\begin{array}{l}\text { Uncertainty and error in experiments and how to minimize and } \\
\text { quantify uncertainty }\end{array}$ \\
\hline Avoiding Mistakes & Proper planning of experiments; sensor response \\
\hline Written Presentation of Results & $\begin{array}{l}\text { Presenting data in graphical and written form; formatting and } \\
\text { content for reports, journal articles, etc. }\end{array}$ \\
\hline Oral Presentation of Results & $\begin{array}{l}\text { Poster presentations, conference and meeting presentations, } \\
\text { presentation techniques, and time management during } \\
\text { presentations }\end{array}$ \\
\hline Graduate School & $\begin{array}{l}\text { Overview of graduate degrees, finding a graduate school, } \\
\text { applying to graduate school, finding an advisor, and funding for } \\
\text { graduate school }\end{array}$ \\
\hline
\end{tabular}

Near the conclusion of the program the participants competed in a poster presentation in order to demonstrate their research progress, utilize the presentation and experimental skills they learned in the seminar series, and to learn about the projects performed by other participants. The posters were judged by four faculty and staff members who were not REU research mentors. Judging was based on formatting, abstract, motivation, diagram of experimental apparatus, results and data presentation, significance of results and conclusions, and oral communication style. In addition to the judges, the event was open to other faculty and staff members in the school of engineering. Titles of student projects were: Laser Micromachining and PDMS Molding of Polyimide to Create Hydrophobic Surfaces, Flow Separation over Low Aspect Ratio Wings, Micro-Optical Magnetometer Based on Whispering Gallery Mode Phenomenon, Design of Radiation Shield for Electron Beam-Plasma Window System, Laser Ablation Characteristics of Polyimide, Fixturing Design for Electron Beam Welding with a Plasma Window, V3V's Solid Deformation Application and Image Processing, Dynamic Testing Capabilities for the E1000 Machine, Polymeric Micro-Optical Sphere as a Wall Pressure Sensor, and Drag Measurement on Self-Propelled Pulsed Jet Underwater Vehicle. 


\section{Survey and Focus Group Measures for Program Evaluation}

The Program Evaluator and her assistant, neither of whom was affiliated with the university's engineering program, gathered quantitative and qualitative information from applicants and participants by way of 5 research activities. In order to guarantee anonymity on the part of the student participants, only the Program Evaluator and her Assistant were allowed access to the data and recordings for analysis. The research efforts were:

-Applicant Profile Survey (optional): Separate from the REU application, the optional Applicant Profile Questionnaire was completed by 42 of the 79 applicants. Applicants were asked to complete the online questionnaire and send it to the host institution via U.S. mail or via email to the PIs, with an assurance that their name would not be associated with their responses. Only the Program Evaluator was allowed access to the questionnaires for analysis. The survey included demographic and academic profile questions, as well as attitudinal statements about engineering and society, engineering education, gender parity, and career aspirations.

-First Day Participant Survey: This 2-page survey was administered on the afternoon of Day 1, immediately before the First Day Focus Group was held. Questions focused on student perceptions of engineering and engineering research; motivation, challenges, goals and outcomes for the REU program; interest in graduate school in engineering; as well as several attitudinal items about engineering education.

-First Day Focus Group: A 1-hour focus group was held in a seminar room and moderated by the Program Evaluator Assistant who followed a Discussion Guide that included items about motivations for application to and perceptions of REU programs and engineering research in general, questions or concerns about the site program in which they had been chosen to participate, and predicted goals and outcomes of the program. Students were asked to participate in a collage activity that involved their selecting pre-cut magazine images and words that best described their prediction of "what the REU experience will be like."

-Final Day Participant Survey: This 2-page questionnaire consisting of closed- and open-ended items taken from the First Day questionnaire was administered on the afternoon of the final day of the REU program, immediately before the Poster Presentation. The questionnaire also focused on evaluating the REU experience and whether current economic conditions were playing a role in educational and career plans.

-Final Day Focus Group: A 1-hour focus group discussion was held in a seminar room and moderated by the Program Evaluator Assistant who followed a Discussion Guide that focused on program evaluation and the impact of the REU program on career aspirations. Participants were again asked to complete a collage activity, this time focused on attitudes toward "engineering research." 


\section{Results}

\section{Applicant Profile Results}

The optional Applicant Profile questionnaire was created to generate data about all REU applicants including demographic information, academic information, origins of interest in engineering, key influencers in the decision to study engineering, salary expectations after graduation, and attitudes about issues in engineering education and the engineering profession. Selected results are described in the following paragraphs.

Seventy completed applications and 9 partial applications were received for the 2009 REU program. The optional applicant questionnaire was returned by 42 applicants (a return rate of $53 \%$ of total applicants), 3 of which were from incomplete applications. The number of applications exceeded those received in Years 1 and 2 of the program. ${ }^{1,2}$ Thirty of the applicants who completed the applicant questionnaire were male and 12 were female. Three-fourths (74\%) were from outside of the state in which the REU program was offered. Three-fourths (32) were White, non-Hispanic (76\%), 4 were Hispanic, 2 were Asian-American, 2 classified themselves as "Other," 1 was African-American, and 1 was Native American/Alaska Native.

Most of the applicants said that at the end of the spring 2009 term, they would be seniors (19 students) or juniors (15), followed by sophomores (7) and first-year students (1). Thirty-five were engineering majors, with 27 listing Mechanical Engineering as their major. Other majors included Aerospace programs (5), Physics (3), Biomedical Engineering (2), Chemical Engineering (2), and others. Most (26) of those who were engineering majors said they decided to study engineering after they entered high school, with most of those making the decision in the junior or senior year. Key influencers in their decision to study engineering were fathers (19), science teachers (16), mothers (14), math teachers (10), friends (8), and others. Six applicants said there was no key influencer in their decision, and only 1 cited a high school counselor as a key influencer.

One-third or more of applicants had participated in at least one of the following: Science Fair (15 students), Talented or Gifted Program (14), Band or Orchestra (14), followed by Math Team (13), Math Counts (5), and other programs.

Thirty applicants (71\%) said they were interested in attending graduate school in engineering. Asked about salary expectations for professional engineering positions, the most frequently cited range for a "first job after graduation" was $\$ 55,000$ to $\$ 60,000$. "Five years from graduation", the most frequently cited salary range was $\$ 75,000$ to $\$ 100,000$.

Asked how they learned about the REU program offered by SMU, applicants reported a variety of ways in which they obtained information about the host site. The most common introduction to REU programs was from the NSF site (11 students), a university or departmental email (9), a friend who had participated or heard of REU (8), the use of a search engine such as Google to find engineering summer employment (7), and other sources. In most cases, students heard about the programs from one source, and then proceeded to follow up primarily via the NSF site or the host university's site. 


\section{First Day and Final Day Survey and Focus Group Results}

Participant Profile. Eight of the participants were male and 2 were female. Six of the 10 were from universities and colleges other than the host institution. The academic standing of participants at the beginning of the program was 1 rising sophomore, 3 rising juniors, and 6 rising seniors, ranging in age from 18-21 years. Eight were mechanical engineering majors, 1 was an engineering science major and another was an aerospace engineering major. All reported a grade-point average of 3.5 or better on a 4.0 scale.

Perceptions of Engineering and Engineering Research. Tables 2 and 3 contain First Day and Last Day "three word" descriptions of engineering and engineering research, respectively. Participant descriptions of the field of engineering - that it is innovative, challenging and technical -- did not change substantially over the 8-week program. Their concepts of engineering research, however, tended to reflect the realities of their time in the laboratory environment. One participant described engineering research on the First Day as "innovative, creative, and exciting," and eight weeks later modified that description to "innovative, creative, and slow." Though post-program words still included "rewarding," "necessary," and "helpful," the highly technical, tedious, and sometimes uncertain nature of their work resulted in participants on the Final Day also using words such as "failure," "erratic," and "monotonous."

Table 2: Participant Descriptions of Engineering Before and After Participation in the REU Program

\begin{tabular}{|c|c|}
\hline $\begin{array}{c}\text { Three Words That Describe } \\
\text { Engineering-First Day }\end{array}$ & $\begin{array}{c}\text { Three Words That Describe } \\
\text { Engineering - Final Day }\end{array}$ \\
\hline $\begin{array}{l}\text { - challenging, changing, cohesive } \\
\text { - precise, technical, necessary } \\
\text { - details, ethics, precision } \\
\text {-diverse, practical, adaptable } \\
\text { - innovation, refinement, creative } \\
\text { - broad, applications, helpful } \\
\text {-challenging, explorative, defined } \\
\text { - innovative, important, practical } \\
\text { - precise, sophisticated, technical } \\
\text { - technical, useful, contribute (to society) }\end{array}$ & $\begin{array}{l}\text {-difficult, innovative, important } \\
\text {-innovative, logical, important } \\
\text { •detailed, specialization, safety } \\
\text { •diverse, practical, interesting } \\
\text { •progress, improvement, original } \\
\text {-productive, helpful, broad } \\
\text { •design, failure, growing } \\
\text {-innovative, creative, design } \\
\text {-precise, thorough, technical }\end{array}$ \\
\hline
\end{tabular}


Table 3: Participant Descriptions of Engineering Research Before and After Participation in the REU Program

\begin{tabular}{|c|c|}
\hline $\begin{array}{c}\text { Three Words That Describe Engineering } \\
\text { Research - First Day }\end{array}$ & $\begin{array}{c}\text { Three Words That Describe Engineering } \\
\text { Research - Final Day }\end{array}$ \\
\hline $\begin{array}{l}\text {-useful, exciting } \\
\text { - forward-thinking, versatile, necessary } \\
\text { - innovative, scientific, beneficial } \\
\text { - ethics, creative, attentive } \\
\text { - interesting, necessary, innovative } \\
\text { - complex, unknown, cutting edge } \\
\text { - helpful, experiments, measurements } \\
\text { - testing, vague, unknown } \\
\text { - innovative, creative, exciting } \\
\text { - experimental, advanced, logistical }\end{array}$ & $\begin{array}{l}\text {-slow, experimental, erratic } \\
\text {-foundational, rewarding, technical } \\
\text { •demanding, necessary, complex } \\
\text { •forward-looking, broad, applications } \\
\text {-focused, necessary, practical } \\
\text {-tedious, unpredictable, revealing } \\
\text {-relaxed, helpful, learning } \\
\text {-failure, monotonous, exciting } \\
\text {-innovative, creative, slow } \\
\text {-experimental, specialized, comprehensive }\end{array}$ \\
\hline
\end{tabular}

Participant Motivation and Program Benefits. Participant motivations and perceived benefits for applying for an REU experience were expressed on the First Day through open-ended responses on the First Day questionnaire (see Tables 4 and 5) and comments during the focus group. Responses reflected the three themes of "figuring out my next move," "preparing me for graduate school," and "giving me experience for interviews." Specific benefits included acquiring practical experience to complement academic work before graduating; learning more about the life of an engineering graduate student; exploring and narrowing specific graduate school and professional fields; earning money during a summer when many part-time jobs were not available due to economic conditions; and building a résumé.

Table 4: Participant Motivation for Participating in the REU program

\begin{tabular}{|c|c|}
\hline & Responses \\
\hline $\begin{array}{l}\text { How would you describe your } \\
\text { motivation for participating in } \\
\text { the REU at SMU program? }\end{array}$ & $\begin{array}{l}\text {-Experience for grad school and learning about research and how } \\
\text { much I like it to decide if I will go to grad school. Also learning } \\
\text { what I like to do (specific fields) in engineering } \\
\text {-I participated in a research program before and enjoyed it so I } \\
\text { wanted to participate again } \\
\text {-I am very motivated because of the opportunities this program } \\
\text { provides for both academic and personal growth } \\
\text {-I am preparing for grad school, therefore this program is giving me } \\
\text { the opportunity to determine more specific studies I will be } \\
\text { pursuing } \\
\text {-I am motivated to practically apply the knowledge I have gained } \\
\text { over the course of my college career. } \\
\text {-I need to get some practical experience in the engineering field } \\
\text { - Location. I wanted to travel somewhere. Program. The program } \\
\text { will be a good career/résumé builder and it has a good stipend. } \\
\text {-It's a great chance to work in a research setting } \\
\text {-I want to get a better idea as to what I want to pursue in grad } \\
\text { school } \\
\text {-I thought it would provide good introductory experience in the } \\
\text { field of engineering }\end{array}$ \\
\hline
\end{tabular}


Table 5: Perceived Benefits of Participating in the REU program

\begin{tabular}{|c|c|}
\hline & Responses \\
\hline $\begin{array}{l}\text { "The main benefits the REU } \\
\text { program provided for me } \\
\text { were......." }\end{array}$ & $\begin{array}{l}\text {-An opportunity at hands on experience, the opportunity to do work } \\
\text { semi-independently, which helped me gain confidence at doing } \\
\text { things on my own } \\
\text {-Enlightening interaction with students from engineering programs } \\
\text { around the country. It was interesting to hear their ideas and } \\
\text { perspectives on the field of engineering and their possible career } \\
\text { paths. The program made me think and recall previous knowledge } \\
\text { on a daily basis, which was a good way to beat the summer slump. } \\
\text { And it was a source of income. } \\
\text {-A good summer job, experience in the lab, and information on if I } \\
\text { wanted to attend grad school } \\
\text { - Learning to communicate with others } \\
\text { - Gaining first hand research experience } \\
\text { - Influencing my decision to go to grad school } \\
\text { - The main benefit was that the experience helped me decide my } \\
\text { plans for the future } \\
\text { - Real-world experience and the opportunity to collaborate on a } \\
\text { research project in the future } \\
\text {-A chance to work in an engineering lab, a goal to work toward for } \\
\text { these eight weeks } \\
\text { - Experience working in real world engineering projects }\end{array}$ \\
\hline
\end{tabular}

Several students mentioned the challenges they faced in explaining the significance of being selected for an REU program to family and friends. While faculty at the participants' respective universities understood the competitive nature of REU selection as well as the opportunity for academic and professional growth that such programs provide, family were more likely to characterize the REU program as an internship or a temporary job. Participants said they felt that being chosen for an REU program was an honor, and this increased their motivation to succeed at their assigned projects. Future program coordinators might include suggested verbiage for and placement of the REU experience on a student résumé or in discussions with prospective employers as well as those unaware of its role and benefits.

Program Outcomes. On the First Day, students were asked to write "what do you plan to learn or be able to do as the result of the REU program?" and on the Final Day they were asked to respond to a similar question that read "Specifically, what did you learn or now are able to do as the result of the REU program?" Table 6 includes their verbatim responses about learning outcomes expected at the outset of the program and those that were realized once the program was completed.

First Day predicted learning outcomes centered on the basics of conducting research and experiencing the laboratory techniques and environment. Unlike responses from the 2007 and 2008 studies $^{1,2}$, participants used the word "academic" frequently to refer both to their environment and the type of research they would be involved with. Final Day outcomes focused on learning the research process as well as other outcomes such as expectations of graduate students and professors, enhancement of specific knowledge and skills, and how to work independently. 
Table 6: Participant Predictions and Assessments of REU Learning Outcomes

\begin{tabular}{|c|c|}
\hline & Responses \\
\hline $\begin{array}{l}\text { Student Predictions from First Day } \\
\text { Specifically, what do you plan to learn or be } \\
\text { able to do as the result of the REU program } \\
\text { at SMU? Please complete the following } \\
\text { sentence: } \\
\text { "As the result of participating in REU, I will } \\
\text { (be able to, learn, understand, etc.)........" }\end{array}$ & $\begin{array}{l}\text {-To learn the process of researching and being able to } \\
\text { document/display/report my results in a professional } \\
\text { manner } \\
\text { - Be more informed about and have a greater appreciation } \\
\text { for the science of fluid mechanics } \\
\text { - Have a better understanding of research from the } \\
\text { perspective of those who have made a career out of it } \\
\text { - more about what it takes to research, creating } \\
\text { experiments, etc. } \\
\text { - Be able to conduct independent research that meets the } \\
\text { standards of the academic community } \\
\text { - Understand what grad school might be like and will } \\
\text { have developed a quality program for my résumé } \\
\text { - Understand engineering and have a better idea of my } \\
\text { future goals } \\
\text { - Gain experience in academic research, serving as a } \\
\text { launch point for future research projects } \\
\text { - I will learn how to conduct research in an academic } \\
\text { environment at a level suitable for graduate school } \\
\text { - Understand how academic experimental research is } \\
\text { conducted and presented }\end{array}$ \\
\hline $\begin{array}{l}\text { Student Assessments from Final Day } \\
\text { Specifically, what did you learn or are now } \\
\text { able to do as the result of the REU program } \\
\text { at SMU? Please complete the following } \\
\text { sentence: } \\
\text { "As the result of participating in REU, I (am } \\
\text { able to, learned, understand, etc.)......." }\end{array}$ & $\begin{array}{l}\text { - Learned what the research environment/life is like at a } \\
\text { graduate school } \\
\text { - Am able to better tackle large projects and work better } \\
\text { with individuals on those projects. I have enhanced my } \\
\text { understanding of some engineering principles covered in } \\
\text { class as well } \\
\text { - Learned about daily life as a grad student, what tasks are } \\
\text { done each day and what is expected } \\
\text { - Learned more of my interests and things I am not } \\
\text { interested in } \\
\text { - Am able to approach problems with a focus on the long } \\
\text { term objectives. I also feel more confident running an } \\
\text { experiment on my own } \\
\text { - Am able to present and gather data better. Decide } \\
\text { whether grad school is for me. } \\
\text {-I earned a lot of great experience in the lab. I } \\
\text { understand a lot about the science behind the research in } \\
\text { my lab. I also learned how to use a lot of equipment that } \\
\text { I will use again in the future. } \\
\text { - Learned many real world engineering skills, especially } \\
\text { in the areas of engineering design and manufacture } \\
\text { - Learned more about mechanical design as well as } \\
\text { machining } \\
\text { - Learned what the process of academic research looks } \\
\text { like }\end{array}$ \\
\hline
\end{tabular}


Program Challenges. On the First Day, participants tended to focus on their perceived lack of knowledge necessary to complete the REU assignments, including learning about equipment, processes, faculty and student colleagues, and the Poster Presentation assignment (see Table 7). Participants on the Final Day were much less likely to focus on acquiring knowledge as a challenge they actually encountered, and much more likely to focus on the challenges of working through complexity, setbacks, errors, and managing projects within a given time frame.

Table 7: Participant Predictions and Assessments of Challenges Associated with the REU Program

\begin{tabular}{|c|c|}
\hline & Responses \\
\hline $\begin{array}{l}\text { Student Predictions from First Day } \\
\text { "For me, the challenges I foresee in the REU } \\
\text { program will be......" }\end{array}$ & $\begin{array}{l}\text { - Presentation at the end of the program } \\
\text { - Completing the project in time, and understanding all } \\
\text { of the theory involved } \\
\text { - Tasks that I do not have the knowledge to complete. } \\
\text { Hopefully I will be able to do enough research to } \\
\text { understand everything I am asked to do } \\
\text { - Understanding and using equipment } \\
\text { - None at this time } \\
\text { - Learning new subjects and understanding the } \\
\text { expectations of my professor } \\
\text {-Learning about research and how it is done } \\
\text {-Working alongside people with much more academic } \\
\text { and professional background than myself } \\
\text {-Balancing the work for the program and the work for } \\
\text { summer classes } \\
\text { - Lack of experience/coursework in the field on account } \\
\text { of my age }\end{array}$ \\
\hline $\begin{array}{l}\text { Student Assessments from Final Day } \\
\text { "For me, the main challenges in the REU } \\
\text { program were......." }\end{array}$ & $\begin{array}{l}\text { - Getting used to things not working out the way they } \\
\text { theoretically should } \\
\text { - Completing the project in the short amount of time we } \\
\text { had to do so. My project required extensive setting up, } \\
\text { some of which I had done before the program began, but } \\
\text { which still took a long time to complete } \\
\text { - Understanding concepts that confused me at first and } \\
\text { developing solutions to experimental problems I ran into } \\
\text {-Keeping busy, know the specific project (overall goal) } \\
\text {-Understanding a complex problem and working to } \\
\text { solve it in only two months time } \\
\text {-Dealing with failure and setbacks } \\
\text {-I had to learn a lot of information and techniques at the } \\
\text { beginning but I became very independent after a few } \\
\text { weeks } \\
\text {-Dealing with a head professor who was a real } \\
\text { (expletive deleted) } \\
\text {-Adapting to working for a whole day, as opposed to } \\
\text { working shifts } \\
\text {-Findings ways to reduce errors in my project } \\
\text { (product??) system }\end{array}$ \\
\hline
\end{tabular}




\section{Attitudinal Statements}

After participating in the REU program, all 10 of the students either agreed or strongly agreed that they were confident about obtaining the position they desired after graduation (see Table 8). Though the same number of students (8) expressed interest in attending graduate school, only 2 agreed strongly, compared with the 5 who strongly agreed before the program began. After 8 weeks in the REU lab setting, students said they felt more knowledgeable about engineering research, were less likely to agree that their own university's engineering curriculum offered adequate "hands-on experience," and felt much more confident that they have adequate experience working with specialized engineering equipment and making engineering measurements.

Table 8: Student Attitudes Before and After REU Participation

\begin{tabular}{|l|c|c|}
\hline & $\begin{array}{c}\text { Before } \\
\text { \# agree } \\
\text { (10 responses) }\end{array}$ & $\begin{array}{c}\text { After } \\
\text { \# agree } \\
\text { (10 responses) }\end{array}$ \\
\hline $\begin{array}{l}\text { I am confident that I will be able to obtain the job I want after graduating } \\
\text { from college. }\end{array}$ & 9 & 10 \\
\hline I am interested in attending graduate school in engineering. & 8 & 8 \\
\hline $\begin{array}{l}\text { I feel that the Engineering curriculum at my current university contains } \\
\text { sufficient ‘hands-on' experience. }\end{array}$ & -- & 8 \\
\hline $\begin{array}{l}\text { I feel that as the result of the REU program at SMU, I now have } \\
\text { considerable 'hands-on' experience in engineering. }\end{array}$ & 1 & 9 \\
\hline I feel I am knowledgeable about engineering research. & 5 & 8 \\
\hline I feel I am knowledgeable about the role of engineering research in society. & 6 & 7 \\
\hline $\begin{array}{l}\text { I feel I have adequate experience in working with teams on engineering } \\
\text { projects. }\end{array}$ & 1 & 8 \\
\hline $\begin{array}{l}\text { I feel I have adequate experience in working with specialized engineering } \\
\text { equipment. }\end{array}$ & 7 & 10 \\
\hline I feel I have adequate knowledge of engineering theory. ${ }^{\dagger}$ & 7 & 8 \\
\hline $\begin{array}{l}\text { I feel I have adequate experience with the proper methods of making } \\
\text { engineering measurements }\end{array}$ & 8 & 8 \\
\hline $\begin{array}{l}\text { I feel I understand the relationship between engineering measurement and } \\
\text { engineering design and theory. }\end{array}$ & & 8 \\
\hline
\end{tabular}

Participant Evaluation and Recommendations. The Final Day focus group allowed participants to make suggestions about how their experience could have been better, as well as to elaborate on what the program meant to them. All of the participants said they were pleased with their decision to pursue an REU program, and that they had benefitted from the experience provided during the eight-week assignment.

\footnotetext{
* A five-point scale from Strongly Agree (5) to Strongly Disagree (1) was used. This table reflects the number who checked a 5 or 4 .

$\S$ Questionnaires for the "Before" measurement were completed on the afternoon of the First Day on campus, following an orientation session. "After" questionnaires were completed on the Final Day, after all REU activities were completed except the Poster Presentation.

** Item asked on Final Day questionnaire only.

${ }^{\dagger}$ One final day respondent did not respond to this question.
} 
Students tended to describe their experience in terms of their degree of understanding of the "big picture" or overall project goal; the quality and type of interaction with their faculty mentor; and whether they "succeeded" in achieving a tangible outcome for their respective projects. Similar to findings of Years 1 and 2, students in Year 3 often mentioned that they did not achieve a feeling of "closure" for their research in the time available. Some suggested that the REU program be extended so that they could finish what they had begun.

Students said they enjoyed the change of pace that working in a laboratory represented, as well as the new "real world" challenges - distinctly different from textbook assignments - that they were faced with. Aspects of the program that they least enjoyed were the tedious nature of the work, which they felt might have been compounded by their lack of understanding of the larger context of their project. Another challenging aspect for some of the students was what they perceived as an unacceptably low level of interaction with their faculty mentors. Other students were very positive about their relationship with their mentors, citing that they felt they not only learned technical information but also formed enough of a relationship with the faculty member that they could ask him or her for a letter of recommendation for a job or for graduate school. Students also expressed a desire to learn more about what their student colleagues were working on. They felt that greater faculty interaction and exposure to other student projects would have helped in their overall understanding of engineering research.

Role of the Economy in Student Career Plans. As part of the Final Day focus group, participants were asked if the current economic recession would likely play a role in their educational or career plans. Half of the students said that their post-graduate decisions may be affected by economic conditions. For most of those students, they felt that attending graduate school during slow economic times would be a good investment in their future career. One student said he/she intended to work in order to have sufficient funds for graduate school later. Several shared anecdotes about friends and acquaintances who had graduated in recent years and had difficulty finding full-time employment. Overall, the group said they would "wait and see" the status of the economy when they need to make career or educational decisions.

\section{Discussion}

Evaluation of a third-year REU site program yielded information about participant expectations, experiences and aspirations.

The third year of an REU site program attracted a greater number of applicants than in Years 1 or 2. Information about the site program in most cases was initially received from a departmental email or other notification, the recommendation of a classmate or friend, or students accessing the NSF site. Prospective applicants then typically followed up by visiting the NSF site if they had not previously, and eventually visiting the host University REU web page. PIs from the site program described herein believe that the increased applicant pool was due to a combination of greater word-of-mouth promotion resulting from Years 1 and 2, wider dissemination of promotional emails and materials to colleagues at other schools, and possibly the relative scarcity of paying engineering opportunities for students during summer. 
There was a consensus among participants that REU programs strengthen students' knowledge of research principles, and allow them to operate in a unique environment for 8 weeks. Students felt like they learned valuable knowledge and skills that are important for their development professionally and academically. Specifically, they said they would benefit from the "hands-on experience" the program provided, as well as a better understanding of engineering research, working with specialized engineering equipment, and proper procedures in making engineering measurements.

There was no consensus and sometimes only weak agreement among participants that the REU program increased their knowledge of engineering theory or the role of engineering research in society, or working in teams. If future programs wish to emphasize theoretical and social aspects of engineering, such material could be introduced in seminars and also integrated into studentfaculty interactions and the Poster Presentations.

Eight of the students in the 2009 program already planned to attend graduate school, and therefore the summer was seen as an opportunity to experience something akin to full-time graduate school in a relatively low-risk environment in terms of commitment. Making a decision whether to pursue graduate studies was expressed as a desired outcome of the program for some. In the Final Day questionnaire, though, 3 of the 8 students gave the same responses that they did on the First Day questionnaire, 1 student strengthened the resolve to attend graduate school, and 4 changed their responses from "Strongly Agree" to "Agree" that they planned to pursue graduate studies. These findings were not surprising in view of similar findings from previous years at this REU site. Though some faculty might view REU programs as recruitment opportunities for graduate studies in engineering, the reality may be that the experience compels some students and discourages others, much in the way that holding an internship or a part-time job in other disciplines affects students' career choices by providing a low-risk opportunity to experience aspects of a particular type of employment. The REU students expressed interest in narrowing their post-graduation decisions, and the REU program seems to have contributed to that process, whether or not it resulted in a greater desire to attend graduate school.

Focus group discussion highlighted the importance of the relationship between student participant and faculty mentor in the student's evaluation of the program. To the extent that students felt that the program could be improved, much of that upside potential lay with faculty members who students wished had spent more time with them and especially time devoted to understanding the "bigger picture" as it related to their specific research tasks. Previous REU cohorts at this site have expressed similar sentiments -- that although they enjoy the freedom to advance their REU projects, they yearn for the type and regularity of feedback that they experience in their engineering courses, which for many is their only point of evaluative reference. If a future REU program returns to this university site, the PIs plan to institute an application for faculty mentors as well as faculty mentor guidelines that hopefully will address these issues.

\section{Conclusions}

Year 3 of the REU site program was considered a success in terms of attracting a large and qualified applicant pool, achieving measurable progress on the research projects involved, and 
realizing learning outcomes for participants, particularly in the areas of using specialized equipment, taking engineering measurements, and learning more about graduate studies in engineering. Eager on their First Day "on the job," most participants gradually came to understand the academic research process to be somewhat slower and more tedious than expected, and eventually realized that the type of "closure" they typically achieved after a semester-long college course would likely elude them in the REU setting. Suggestions for enhancing future REU programs include managing student expectations for faculty mentor interaction; providing additional guidelines for training and selection of faculty mentors; and making additional efforts to help student participants discern the "bigger picture" of where their projects fit in the scheme of a larger research effort or society in general.

\section{Acknowledgement}

This material is based upon work supported by the National Science Foundation under Grant No. 0649032.

\section{References}

1. D.A. Willis, P.S. Krueger, and A. Kendrick, 2008, "The Influence of a Hands-on Research Experience on Undergraduates Students' Perceptions of Engineering Research," Proceedings of the ASEE 2008 Annual Conference and Exposition.

2. D.A. Willis, P.S. Krueger, and A. Kendrick, 2009, "The Influence of a Research Experiences for Undergraduates Program on Students' Attitudes toward Engineering Research,” Proceedings of the ASEE 2009 Annual Conference and Exposition.

3. R.M. Felder and L.K. Silverman, 1988, "Learning and Teaching Styles in Engineering Education," Engineering Education, Vol. 78(7), pp. 674-681.

4. R.W. Freeman, 2000, "Undergraduate Research as a Retention Tool," $30^{\text {th }}$ Frontiers in Education Conference, Vol. 1, p. F1F-21.

5. B.A. Nagda, S.R. Gregerman, J. Jonides, W. Von Hippel, and J.S. Lerner, 1998, "Undergraduate StudentFaculty Research Partnerships Affect Student Retention,” The Review of Higher Education, Vol. 22(1), pp. 5572. 